\title{
The Relationship between Attachment Styles, Love Types, Emotional Expression and Life Satisfaction
}

\author{
Arş. Gör. Seda Merve ŞAHİN* \\ Orta Doğu Teknik Üniversitesi, Fen-Edebiyat Fakültesi, Psikoloji Bölümü, Ankara / Türkiye, \\ sahins@metu.edu.tr, ORCID: 0000-0003-1503-5292 \\ Arş. Gör. Sami ÇOKSAN \\ Orta Doğu Teknik Üniversitesi, Fen-Edebiyat Fakültesi, Psikoloji Bölümü, Ankara / Türkiye, \\ scoksan@metu.edu.tr - sami.coksan@erzurum.edu.tr, ORCID: 0000-0003-2942-1506
}

\begin{abstract}
The current study examines the association between attachment styles in romantic relations and love type preference, emotional expression, and life satisfaction. Two hundred twenty-six volunteers participated in the study. Results showed that participants who were securely attached to their romantic partners preferred Eros love type more, while participants who were insecurely attached to their romantic partners decided on Ludus, Pragma and Mania love types. There was no difference between secure and insecure attachment styles in terms of Storge and Agape love types. Moreover, there was no difference between groups in terms of general emotional expression. Participants who were securely attached had higher life satisfaction than those who were insecure. It is argued that differentiation power on emotional expression and life satisfaction might be obtained with studies about attachment styles in the romantic relationship.
\end{abstract}

Keywords: Attachment style; Emotional expression; Life satisfaction; Love types; Romantic relationship. 


\title{
Bağlanma Stilleri ile Aşk Tipleri, Duygusal Dışavurum ve Yaşam Doyumu Arasındaki İlişki
}

\begin{abstract}
$\ddot{O} z$
$\mathrm{Bu}$ çalışma romantik ilişkilerde bağlanma stilleri ile aşk tipi tercihi, duygusal ifade ve yaşam doyumu arasındaki ilişkiyi incelemektedir. Çalışmaya 226 gönüllü katılmıştır. Sonuçlar, romantik partnerlerine güvenli bağlanmış katılımcıların Eros aşk tipini; görece güvensiz bağlanmış katılımcıların ise Ludus, Pragma ve Mania aşk tiplerini tercih ettiklerini göstermiştir. Romantik partnerlerine güvenli ve güvensiz bağlanan katılımcıların Storge ve Agape aşk tipi tercihleri arasında bir farklılık görülmemiştir. Ayrıca, partnerlerine güvenli ya da güvensiz bağlanan gruplar arasında genel duygusal dışavurum açısından anlamlı bir farklılık yoktur. Son olarak, romantik partnerlerine güvenli bağlanan katılımcıların, güvensiz olanlardan daha fazla yaşam doyumuna sahip oldukları belirlenmiştir. Romantik ilişkilerde bağlanma stillerine yönelik çalışmalar ile duygusal dişavurumlar ve yaşam doyumuna yönelik farklılaştırma gücünün elde edilebileceği tartışılmıştır.
\end{abstract}

Anahtar Kelimeler: Bağlanma stilleri, Duygusal dişavurum, Yaşam doyumu, Aşk tipleri, Romantik ilişkiler.

\section{Introduction}

Our close relationships are one of the cornerstones of our lives. They affect our life satisfaction and emotions. Moreover, our attachment patterns, which are mostly affected by past experiences, shape our romantic relations, as well. Our love styles are one of the factors that are shaped by those experiences. Do our attachment styles affect our love preferences? Can the way we express our past experiences influence our feelings? Is our life satisfaction connected to our relationship with our partners? This study tries to answer these questions. In this study, we focus on examining the relationship between attachment styles and love types, emotional expression, and life satisfaction.

The concept has been examined within the framework of intimacy and commitment since the first studies, although love has been conceptualized in many different ways in the scientific research process (Reis and Aron, 2008). For example, whereas Berscheid and Walster (1978) conceptualized love between passionate love and companionate love, Sternberg (1986) included commitment and intimacy in theory. Some studies (e.g., Aron and Westbay, 
1996; Hendrick and Hendrick, 1986; Lee, 1973; Madey and Rodgers, 2009; Sternberg, 1986) show the formation of love with three components as supported in Sternberg's Triangular Love Theory. Based on this theory, commitment refers to the decision to love someone in the short term and maintain the relationship in the long term, whereas intimacy refers to feelings of closeness and connectedness in romantic relationships. On the other hand, passion refers to drives, such as physical attractiveness, romance, and sexual consummation in romantic relationships (Sternberg, 1986). Even though there are many definitions of love; six types of love (Lee, 1973) are emphasized according to Hendrick and Hendrick (1986). These are called Eros type, Ludus type and Storge type as primary styles of love, and also Mania type, Pragma type, and Agape type as secondary styles of love. Each type has its unique characteristics. For instance, strong physical preferences, charm, emotional intensity, and commitment are observed on Eros type of love.

On the other hand, the people who prefer the Ludus type of love evaluate love as an interactive game played with different partners. Storge type indicates a strong relationship and friendship, but there is almost no passion. Pragmatic type can be considered as a rational calculation. For instance, people with pragmatic love type evaluate love as a plan, and according to them, love has specific criteria. Furthermore, Mania type includes uncertainty of self and the lover, while Agape can be defined as selfless, altruistic love (Hendrick and Hendrick, 1986).

Different conceptualizations of love are considered to be an attachment process. To explain more clearly, an infant's reactions to the absence of caregivers or the connection between them can be considered as attachment in early childhood. Their attachment system presents a relation with other behavioral systems such as exploratory system, fear system, caregiving system, and sociable system (Cassidy, 2008). Thus, their bonds, which are shaped in earlier childhood, affect the romantic attachment pattern in adulthood. Attachment Theory (Bowlby, 1969, 1973, 1980) offers a dynamic approach when explaining how close relationships are shaped and formed, while it uncovers healthy and unhealthy situations in relationships' origins at the same time. In this context, Hazan and Shaver (1987) argue that romantic relationships in adulthood can be explained based on attachment theory, which is based on the bonds babies form with their parents. The 
attachment that is formed between babies and their mothers is learned, and this bond is applied to other relations in their environments (such as romantic partners and friendships, etc.); that is called adult attachment (Garrison, Kahn, Sauer and Florczak, 2012). The attachment patterns developed in infancy affect our relationships even in adulthood.

According to Bowlby (1969), attachment is characterized by specific behaviors in children. These specific behaviors in childhood can vary based on behaviors that involve the responsiveness and intimacy of mothers or caregivers. For instance, Ainsworth (1979) showed that reactions of children to separation could be examined under three different groups according to the behavior of children toward their mothers. These groups can be called as Group A, Group B, and Group C. The children who are in Group B use their mother as a secure base in pre-separation parts, and they seek contact or closeness with their mothers when their mothers return to the situation. On the other hand, the children who are in Group $C$ show some signs of anxiety even in pre-separation parts, and their behaviors, which include seeking proximity or contact, are ambivalent when their caregivers return. In contrast, the children who are in Group A rarely cry at separation parts and avoid their mothers when they return. These groups are called secure, anxious, and avoidance attachment styles. These patterns can be seen in romantic relationships as a reaction toward the partner rather than the parent or caregiver (Feeney, 2016). For instance, adults seek proximity or contact with their partners in stressful times. On the other hand, they can protest their partners' availability (Weiss, 1982).

Further studies have shown that the conceptualization of attachment styles in 3 categories is not enough to clarify adult attachment characteristics. In this regard, Bartholomew (1990) presented a model to explain the adult attachment system with four categories, which are called secure, preoccupied, fearful, and dismissing attachment styles. The model that is used in our study emphasizes that the secure attachment style is related to positive self and other models. In brief, individuals who are securely attached think that their self is worthy and others are trustworthy. Preoccupied styles include positive other models and negative self-model. Thus, these individuals think that their self is unworthy and they have to gain others' approval. Fearful styles consist of both the negative self and another model. They avoid social situations and experience fear of rejection. Lastly, 
dismissing styles refer to the positive model of the self and negative model of others. They see themselves as worthy and passively avoid close relationships. In this context, individuation and connectedness are fundamental concepts of the adult attachment system.

The patterns shown in childhood are examined and conceptualized based on romantic love as an attachment process afterward by Hazan and Shaver (1987). In their study, secure attachment is characterized by trust, friendship, and positive emotions depending on an adult's romantic attachment pattern. Adults who are attached to their partner securely find their partners trustworthy, and they find themselves likable. Other studies (e.g., Stephan and Bachman, 1999) also emphasize that individuals who are securely attached to their partners tend to display high levels of trust, commitment, and acceptance in their relationship. When we consider love types concerning attachment types, studies are emphasizing that Eros type of love represents being secure in love, maintaining a commitment to a relationship, and being sincere about the relationship.

On the other hand, individuals who engage in Agape type love are generally very supportive of their partner, and they show higher tolerance to their partner in the relationship (Galinha, Oishi, Pereira, Wirtz and Esteves, 2014). These characteristics of Eros type and Agape type are considered to be compatible with secure attachment patterns in adulthood based on commitment and acceptance. Moreover, individuals who prefer Eros or Agape type show more of a tendency toward secure attachment feelings (Karandashev, Benton, Edwards and Wolters, 2012). Besides, Shaver and Hazan (1988) made a formulation between secure attachment with Eros type of love and Agape type of love. The connection between secure attachment and the Agape love type is also supported by Bugay and Tezer (2008). Also, while Eros love type is positively associated with secure attachment, it is negatively associated with insecure attachment (Fricker and Moore, 2002).

Moreover, Eros and Agape love type preferences were positively related to positive relationship characteristics (Costa, Sophia, Sanches, Tavares and Zilberman, 2015). Noh, Park and Kim (2006) further showed that Eros and Agape love types are associated with secure attachment. Hence, we hypothesized that people who are securely attached to their partners would prefer Eros type of love more than insecure people do 
(Hypothesis 1a), and people who are securely attached to their partners will prefer Agape type of love more than insecure people do (Hypothesis 1b).

Anxious attachment as a subtype of insecure attachment is related to jealousy and involves obsessions. They can easily and frequently fall in love but have difficulty finding true love. They are expected to experience love as a painful, challenging struggle to merge with another person (Hazan and Shaver, 1987). Other studies emphasized that anxious styles are characterized by low satisfaction in their relationship and low trust in their partners, but their relationships include high, obsessive commitment (Stephan and Bachman, 1999). Honari and Saremi (2015) showed that ambivalent anxious attachment is related to mania love type.

Moreover, anxious attachment's characteristics involve thinking of themselves as misunderstood and unconfident, as well as finding significant others unreliable. Furthermore, they are unwilling to commit themselves to permanent relationships (Simpson, 1990). Shaver and Hazan's (1988) formulation indicated that there is a relationship between anxious attachment and Mania type love. Furthermore, anxious-ambivalent adults have higher scores on Mania type love preference (Feeney and Noller, 1990; Fricker and Moore, 2002) and preoccupied adults who have high scores on anxious attachment style and low scores on avoidant attachment style exhibited Mania love type (Bugay and Tezer, 2008).

Another subtype of insecure attachment is avoidant style. The avoidant style is characterized by fear of intimacy, emotional highs and lows, and jealousy. Hazan and Shaver (1987) evaluated that they tend to be more doubtful of the existence or durability of romantic relations. In addition to these, Stephan and Bachman (1999) showed that the avoidant style is characterized by both low commitment to romantic relationships and low trust to partner. Otherwise, avoidant styles think that they are unreliable and skeptical, but at the same time, they think that they are essential, and they are overeager to commit themselves to relationships (Simpson, 1990). When the Mania type, Pragma type and Ludus type are examined based on attachment styles, Mania type is seen as an obsessive, jealous and very emotional love style. People who prefer this love style are characterized by their insecurities about their relationships and they display intense fear that their feelings will not be reciprocated. 
On the other hand, Pragma types are not interested in physical appearance and they are not very emotional. They want the relationship to be a success. These characteristics of Pragma types indicate a need for safety in the relationship. Pragma type of love is considered to be related to dismissing attachment as a form of insecure attachment (Adil and Kamal, 2005). Lastly, the Ludus type is characterized by relationships that are not serious. They prefer more than one partner and avoid commitment (Galinha, Oishi, Pereira, et al., 2014). These characteristics of Pragma type, Ludus type, and mania type are seen to be compatible with insecure attachment patterns in adulthood based on obsession, distrust, and fear of feelings.

Moreover, individuals who have Ludus type and Mania type show more of a tendency toward insecure attachment feelings (Karandashev, Benton, Edwards and Wolters, 2012). Shaver and Hazan (1988) state that avoidant attachment is related to Ludus type of love. The relationship between Ludus love type and avoidant attachment is supported in Smith and Klases' study (2016). Levy and Davis (1988) specify that in contrast to secure relationship characteristics, Ludus type of love includes negative relationship characteristics such as high conflict and low satisfaction. Moreover, Feeney and Noller (1990) claim that insecure attachment is related to Mania love type. Recent studies showed that there is a significant correlation between insecure attachment types and Mania love type (Noh, Park and Kim, 2006) and anxious attachment and Mania love type (Smith and Klases, 2016). Thus, under these findings, we hypothesized that there would be a difference between secure and insecure attachment style in terms of preference toward Mania love type. We think that people who are insecurely attached to their partners will show a higher preference for Mania love type (Hypothesis 2a). People who are insecurely attached to their partners will show a higher preference for the Pragma love type (Hypothesis $2 b)$. On the other hand, people who are insecurely attached to their partners will prefer Ludus love type more than others (Hypothesis 2c).

Storge love is characterized as an extension of friendship. It is marked by a tendency to share activities and common interests (Galinha, Oishi, Pereira, et al., 2014). As mentioned by Shaver and Hazan (1988), Storge love may not constitute a form of romantic attachment. Furthermore, Storge love is formed based on friendship (Galinha, Oishi, Pereira, et al., 2014; Grote and Frieze, 1994; Levy and Devis, 1988). Therefore, we wanted to 
examine it, and we hypothesized that there would be no significant difference between adults' romantic attachment patterns to prefer the Storge type of love (Hypothesis 3).

In sum, a review on the relationship between attachment types, love types, emotional expression, and life satisfaction revealed that Eros type of love is positively correlated with secure attachment, marital satisfaction, and intense positive feelings. In the same way, the Agape type of love is associated with relational satisfaction and secure attachment. On the other hand, Storge type of love is seen as a form of friendship, and it is related to relationship satisfaction. However, Ludus type of love is considered risky for relationship satisfaction, and it is related to insecure attachment type. In contrast, while the Pragma type is associated with personal well-being, it is preferred by persons who are insecurely attached. Lastly, Mania type of love was found to be related to insecure attachment and less satisfaction (Raffagnino and Puddu, 2018). Also, another study supported that secure attachment is associated with Eros type of love and Agape type of love, but insecure attachment types are associated with Ludus, Pragma and Mania love types (McWalter, 2012).

Our third dependent variable is the emotional expression. It is defined as verbal or non-verbal observable behaviors that represent an emotional or communicative experience (Kennedy-Moore and Watson, 2001). There is an association between attachment styles and emotional expression as well. For instance, Bowlby (1969) (see also, Sbarra and Hazan, 2008) mentioned that the association between attachment styles and emotions is a consequence of separation or loss; however, relatively new studies that examine the relationship between emotional expression and attachment styles are very limited. Moreover, Mikulincer and Shaver (2007) claimed that people who are securely attached to their attachment figure could easily express their emotions in stressful situations since they do not deny their negative emotions and they know their relationships are secure when it comes to dealing with these negative emotions.

On the other hand, people who are avoidantly attached to their attachment figure cannot take the risk of allowing their emotions to flow free. Their defense system is designed to inhibit emotional states. Avoidant individuals also avoid proximity-enhancing behaviors because of their avoidance of intimacy. For this reason, they may feel uncomfortable with joy 
and happiness, and they attempt to block emotional reactions. Unlike avoidant people, people who are anxiously attached to their partner exaggerate their negative emotions. They attempt to sustain and intensify their emotions.

Some studies (e.g., Stroebe, Schut and Stroebe, 2006) emphasized that insecurely attached people gain favor from self-disclosure more than securely attached people do. When self-disclosure is considered as an expression method independent of emotions, insecure individuals can take advantage of self-disclosure more than securely attached people do, because securely attached people express themselves more than insecurely attached individuals. Besides, when people are dismissingly attached to their partner as a substyle of insecure attachment, this restricts their emotional expression, but securely attached people can easily express themselves in stressful situations (Stroebe, Schut and Stroebe, 2005). Additionally, some findings (e.g., Tacón, Caldera and Bell, 2001) showed that avoidant individuals could suppress their negative emotions. Moreover, Garrison, Kahn, Sauer, et al. (2012) demonstrated that people with high attachment avoidance showed less emotional disclosure than less avoidant participants. In addition, studies show that while securely attached individuals exhibit a wide range of emotional expression, insecurely attached individuals show a narrow range of emotional expression (Mikulincer and Shaver, 2005). Based on these findings, we hypothesized that people who are securely attached to their partners would express greater general emotion (Hypothesis 4).

Our last dependent variable is life satisfaction. It is conceptualized as "an overall assessment of feelings and attitudes about one's life at a particular point in time ranging from negative to positive" (Prasoon and Chaturvedi, 2016). Reizer (2015) showed that attachment anxiety and avoidance are negatively associated with life satisfaction in a sample that is formed by employees. Moreover, the secure attachment style is significantly associated with higher well-being, whereas preoccupied attachment has the most adverse effect on well-being. Furthermore, dismissing attachment had a positive effect on well-being, but the fearful attachment was not directly associated with well-being (Karreman and Vingerhoets, 2012). Moreover, people who were attached to their partner insecurely were less likely to be satisfied in their relationships (Fraley, Heffernan, Vicary and Brumbaugh, 2011). Related to these findings, we hypothesized that people who are 
securely attached to their partners have more life satisfaction than others (Hypothesis 5).

As mentioned above, we focus on the relationship between attachment style and (a) love type, (b) emotional expression, and (c) well-being. Although there are findings in the literature supporting the relationship between love types and attachment, these studies are generally examined based on Sternberg's (1986) Triangular Love Theory. However, in the current study, Lee's love types (1988) were used instead of Triangular Love Theory. As mentioned before, whereas Triangular Love Theory consists of three fundamental concepts such as passion, intimacy, and commitment, Lee's love types can correspond to various combinations of these three concepts and their levels, and other characteristics. For example, whereas Eros type of love contains high commitment and passion, Storge type of love does not contain passion (Hendrick and Hendrick, 1986). Thus, Lee's Love Types provide a broader definition. Therefore, we present new findings from a broader perspective. Besides, emotional expression and life satisfaction are important concepts when we take cultural effects into account (Yetim, 2001). Thus, the current study, which evaluates the attachment style, love type, emotional expression, and life satisfaction in Turkish culture, will provide unique contributions. Considering the cultural differences related to emotional expression and life satisfaction, conducting this study in a Turkish sample will provide essential findings.

As mentioned above, to sum up, we hypothesized that people who are securely attached to their partners would prefer Eros and Agape love types more than those who are insecure do; people who are insecurely attached to their partners will show a higher preference for Mania, Pragma and Ludus love types. However, we do not expect any differentiation between securely and insecurely attached people in terms of preference towards the Storge love type. Moreover, we hypothesized that secure people would express greater general emotion and have higher life satisfaction.

\section{Method}

\section{Participants}

Two hundred and seventy-six people participated in the study in the last quarter of 2016. Fifty participants were excluded from the study because they expressed that they do not have a romantic relationship. Finally, analyses were conducted with 226 participants. Age mean was 24.24 (from 
16 to 62 ) and their relationship period mean was approximately 44 months (from 1 to 396). The economic level (house income/people who lived in the home) mean was 2266 Turkish Liras. Approximately half (45\%) of the participants have a bachelor's degree (35\% high school, $11 \%$ associate degree, 9\% master, 1\% Ph.D.). All participants mentioned that they were heterosexual, and a large part $(45 \%)$ of romantic partners of theirs was their boyfriends or girlfriends (15\% married, 3\% engaged, $9 \%$ others). Demographics are presented in Table 1, below.

Table 1. Demographics of the Participants

\begin{tabular}{llcc}
\hline & & $\mathbf{n}$ & $\mathbf{\%}$ \\
\hline Sex & Female & 182 & 80.5 \\
& Male & 44 & 19.5 \\
\hline Level of Education & Highschool & 79 & 35 \\
& Associate Degree & 24 & 10.6 \\
& Bachelor & 102 & 45.2 \\
& Graduate $^{\mathrm{a}}$ & 21 & 9.2 \\
\hline Romantic Partner Type & Wife or Husband & 34 & 15 \\
& Fiancée & 7 & 3.1 \\
& Girlfriend or Boyfriend & 165 & 73 \\
& Others $^{\mathrm{b}}$ & 20 & 8.9 \\
\hline Relationship Period as Months & $<12$ & 58 & 25.7 \\
& $12-24$ & 29 & 12.9 \\
& $24-36$ & 40 & 17.7 \\
& $36-48$ & 21 & 9.3 \\
& $48-60$ & 17 & 7.4 \\
& $60-72$ & 20 & 8.9 \\
& +72 & 41 & 18.1 \\
\hline
\end{tabular}

Note. ${ }^{\text {a }}$ Participants whose master or doctorate degree. ${ }^{\mathrm{b}}$ Both my wife or husband and girlfriend or boyfriend ( $\left.\mathrm{n}=6\right)$, Both my fiancée and girlfriend or boyfriend $(n=5)$, My best friend $(n=2)$, The woman I would like to marry $(n=1)$, The person I would like to marry, $(n=1)$, The women that perfect me $(n=1)$, The person who treated me best $(n=1)$, My life $(n=1)$, My everything $(\mathrm{n}=1)$, Meaning of my life $(\mathrm{n}=1)$.

\section{Measures}

\section{Experiences in Close Relationships-Revised}

We used Experiences in Close Relationships-Revised Scale to evaluate participants' attachment patterns in the context of their romantic relationships. It was developed by Fraley, Waller and Brennan (2000), and it consisted of avoidance and anxiety factors. In the original paper, Cronbach's Alpha was .81 for both factors. Selçuk, Günaydın, Sümer and Uysal (2005) translated and adapted it into Turkish, and Cronbach's Alpha was .90 and .86 , respectively. We also found that $\alpha=.89$ for the avoidance factor, $\alpha=.88$ for anxiety factor in this study. It was 7 points Likert scale, and a higher score indicated more avoidance and anxiety. 


\section{Love Attitudes Scale: Short Form}

Participants' love types were measured using the Love Attitudes Scale: Short Form, which was developed by Hendrick, Hendrick and Dicke (1998) and translated and adapted into Turkish by Büyükşahin and Hovardaoğlu (2004). It consisted of three main factors that specified Eros, Ludus, and Storge love types. There are also questions about another three types of love that are obtained from combinations of three factors on the scale, Pragma (Ludus+Storge), Mania (Eros+Ludus) and Agape (Eros+Storge). In the translation scale, Cronbach's Alpha of Ludus and Mania was below the acceptable limit, $\alpha=.47$ and $\alpha=.51$, respectively. We also found similar levels of alpha, $\alpha=.59$ for Ludus type and $\alpha=.48$ for Mania type in this study, although Cronbach's Alphas of other love types were upper than .70, which means that Cronbach's Alphas were at acceptable statistical levels. It was 7 points Likert scale, and a higher score defined stronger preference about that love type.

\section{Berkeley Expressivity Questionnaire}

Emotional expressivity, which was one of the dependent variables in this study, was measured using the Berkeley Expressivity Questionnaire (Gross and John, 1995). The total score of this scale with three subdimensions (Positive Expressivity, Negative Expressivity, and Impulse Strength) was evaluated as the general emotional expression of participants. Cronbach's Alphas of the factors of the scale-which were translated and adapted by Akın (2011) were $\alpha=.71, \alpha=.72, \alpha=.76$, respectively, and all scale Cronbach's alpha was .85. The scale was 7 points Likert scale, and a higher score indicated greater general emotional expression.

\section{The Satisfaction with Life Scale}

The life satisfaction variable was measured with The Satisfaction with Life Scale (Diener, Emmons, Larsen and Griffin, 1985), which was translated into Turkish by Yetim (1993). The scale consisted of 5 items and one factor $(\alpha=.90)$. Like our other scales, it was also 7 points Likert scale, and a higher score indicated greater life satisfaction.

\section{Procedure}

The covered aim of the study was shared on the social media pages of universities. Participants agreed to participate in it voluntarily. Firstly, they filled up the demographic and then answered Experiences in Close Relationships-Revised, Love Attitudes Scale: Short Form, Berkeley 
Expressivity Questionnaire and The Satisfaction with Life Scale, respectively. We presented information about the study at the end of the study. The procedure was conducted online between July and September 2018, and it took approximately 15-20 minutes.

\section{Results}

\section{Analytic Approach}

Experiences in Close Relationships-Revised scale provides just the participants' avoidance and anxiety scores; however, the aim of the study examines whether secure or insecure attachment styles differentiate love type preference, emotional expressivity, and life satisfaction; thus, it was necessary to divide the participants into two groups as people with secure and insecure attachment, using these scores. For this reason, we conducted a $\mathrm{k}$-mean cluster analysis ${ }^{1}$ with ten maximum iterations and .2 convergence criterion for scores of avoidance and anxiety. After two iterations, descriptive statistics of k-mean cluster analysis were shown in Table 2 below.

Table 2. Descriptive Statistics of k-Mean Cluster Analyses for Avoidance and Anxiety Scores

\begin{tabular}{|c|c|c|c|c|c|c|c|}
\hline & \multicolumn{4}{|c|}{$\begin{array}{c}\text { Distances Between } \\
\text { Final Cluster Centers }\end{array}$} & \multirow[t]{2}{*}{$\mathbf{n}$} & \multicolumn{2}{|c|}{ Initial Cluster } \\
\hline & (1) & (2) & (3) & (4) & & Avoidance & Anxiety \\
\hline Dismissive Avoidant Attachment (1) & & & & & 35 & 5.56 & 1.72 \\
\hline Fearful Attachment (2) & 2.06 & & & & 17 & 5.94 & 4.50 \\
\hline Secure Attachment (3) & 1.63 & 3.20 & & & 103 & 1.00 & 1.89 \\
\hline Preoccupied Attachment (4) & 1.56 & 1.64 & 1.79 & & 71 & 2.50 & 5.89 \\
\hline
\end{tabular}

To examine whether our clusters were differentiated from each other in terms of avoidance and anxiety scores, we conducted MANOVA. As we expected, our clusters seemed to fit with theoretical background in accordance with the Four Categories Model (FCM) (Bartholomew, 1990), and they were differentiated from each other in terms of avoidance $[F(3.222)=141.84, p<.001$, partial $\eta 2=.66)$ and anxiety $(F(3.222)=154.80$, $p<.001$, partial $\eta 2=.68$ ]. For instance, secure style showed lower avoidance than dismissive-avoidant style, lower anxiety than preoccupied style, and lower both avoidance and anxiety than fearful style at a significance level of .001 for each. Moreover, other styles also provided a theoretical framework of FCM at the same significance level; thus, we grouped dismissiveavoidant, fearful, and preoccupied styles as insecure. To examine whether 
our grouping process was valid or not, we compared secure and insecure groups in terms of avoidance and anxiety. The results demonstrated that the insecure group showed higher avoidance $[F(1.224)=182.35, p<.001$, partial $\eta 2=.45, \bar{x}=2.99]$ and anxiety $[F(1.224)=165.25, p<.001$, partial $\eta 2=.43$, $\bar{x}=4.19$ ] than secure group $[\bar{x}=1.77, \bar{x}=2.88$, respectively]. Hence, we continued with further analyses with this grouping for the attachment style that is our independent variable.

\section{Testing of Hypotheses}

We conducted multivariate variance analysis (MANOVA) to examine the first three hypotheses. Results demonstrated that the participants who were securely attached to their romantic partners preferred Eros love type more $\left[F(1.224)=20.20, p<.001\right.$, partial $\left.\eta^{2}=.08, \Delta \bar{x}=.67\right]$ while other participants opted for Ludus $\left[F(1.224)=6.01, p<.05\right.$, partial $\left.\eta^{2}=.03, \Delta \bar{x}=.31\right]$, Pragma $\left[F(1.224)=6.47, p<.05\right.$, partial $\left.\eta^{2}=.03, \Delta \bar{x}=.43\right]$ and Mania $\left[F(1.224)=14.10, p<.001\right.$, partial $\left.\eta^{2}=.06, \Delta \bar{x}=.53\right]$ love types. There were no differences between secure and insecure attachment styles in terms of Storge and Agape love types.

Moreover, we run the variance analysis (ANOVA) to investigate whether any difference between secure and insecure groups in terms of general emotional expression. There was no difference between groups. We used variance ANOVA again to examine the association between attachment styles and life satisfaction, the last hypothesis. Participants with secure attachment style had greater life satisfaction than insecure ones $\left[F(1.224)=10.14, p<.01\right.$, partial $\left.\eta^{2}=.04, \Delta \bar{x}=.57\right]$. Furthermore, only Eros love type predicted life satisfaction $[F(6.225)=10.24, p<.001, t=5.82, \beta=.40)$. We presented the correlation table below to demonstrate a holistic perspective.

Table 3. Correlations between Love Types, Emotional Expression and Life Satisfaction

\begin{tabular}{lcccccccc}
\hline & $(1)$ & $(2)$ & $(3)$ & $(4)$ & $(5)$ & (6) & (7) & (8) \\
\hline Eros Love Type (1) & 1 & $-.23^{* *}$ & $.21^{* *}$ & .02 & $.13^{*}$ & $.41^{* *}$ & .12 & $.45^{* *}$ \\
Ludus Love Type (2) & & 1 & -.09 & $.14^{*}$ & .06 & -.10 & -.07 & $-.18^{* *}$ \\
Storge Love Type (3) & & & 1 & .12 & .04 & .11 & .002 & $.14^{*}$ \\
Pragma Love Type (4) & & & & 1 & $.27^{* *}$ & $.15^{*}$ & .12 & .08 \\
Mania Love Type (5) & & & & 1 & $.40^{* *}$ & $.21^{* *}$ & .03 \\
Agape Love Type (6) & & & & & 1 & .001 & $.24^{* *}$ \\
General Emotional Expression (7) & & & & & 1 & .02 \\
Life Satisfaction (8) & & & & & & 1 \\
\hline Note. ${ }^{* *}$ Correlation is significant at the .01 level (two-tailed). ${ }^{*}$ Correlation is significant at the .05 level (two-tailed).
\end{tabular}




\section{Discussion}

This study was conducted to understand the relationship between attachment styles and love types, emotional expression, and life satisfaction. We were mostly focused on the association of attachment styles with other factors such as the preference of love styles, expression of emotion, and life satisfaction. Our first hypothesis was that people who are securely attached to their partners would prefer Eros type of love more, compared to people who are insecurely attached. The results suggested that individuals who have been securely attached to their partners preferred Eros love type more than individuals who have been insecurely attached to their partners, as consistent with our hypothesis. This result supports that secure attachment styles are related to positive emotional love styles (Hazan and Shaver, 1987). Besides, while this relationship is supported by other studies in different cultures (Galinha, Oishi, Pereira, et al., 2014), this finding is important to understand the relationship between attachment styles and love types in the Turkish sample. Attachment styles and their effects can be different across cultures. As mentioned by Schmitt (2010), the romantic attachment can be influenced or moderated by the culture and context. In this regard, our study showed that Eros love style was mostly preferred by individuals who are securely attached to their partners in Turkish culture as well. As known, the pattern of relationship between the caregiver and the baby is seen between the partners in romantic relationships (Garrison, Kahn, Sauer and Florczak, 2012). In this context, it is an expected finding that secure attachment type, which is shaped by the commitment and emotional intensity between caregiver and baby, prefers Eros love type with the same characteristics.

Our second hypothesis was that individuals who are securely attached to their partners would prefer the Agape love type; however, our hypothesis was not supported. Although some characteristics of Agape love type such as being supportive of the partner and to show higher tolerance is seen compatible with secure attachment type, there are also findings emphasizing that extreme dimensions of Agape love type are related to the anxiousambivalent attachment as a sub-style of insecure attachment (see, Feeney and Noller, 1990). Furthermore, it is seen to be compatible with secure style in terms of being supportive of the partner and being selfless, but some patterns of it such as altruistic behaviors can be related to an anxious attachment which includes sensitivity to rejection and expectation of mutual love (Stephan and Bachman, 1999). Because we did not divide insecurely 
attached individuals into subcategories in our study (dismissive-avoidant, fearful, preoccupied) due to sample size, we may have missed the relationship between them; thus, preference of Agape type love can be examined based on dimensions of insecure attachment for future studies.

Another hypothesis was that people who are insecurely attached to their partners would choose Mania love type. Although it was supported, the reliability coefficients of Mania love type in the translated Turkish scale $(\alpha=.47)$ and in our analysis $(\alpha=.48)$ were too low. Therefore, it should be taken into consideration that this result may not present a reliable finding as opposed to being supported. In the same way, although the Ludus love type's reliability coefficient was so low, the results of the analysis showed that Ludus love type is related to insecure attachment style. The characteristic of Ludus love type is to avoid commitment, which supports simultaneous relations with more than one person (Galinha, Oishi, Pereira, et al., 2014), and it is also seen as a characteristic of insecure attachment style (Stephan and Bachman, 1999). In this regard, the relationship with insecure attachment is consistent with the literature.

Another hypothesis emphasizing that insecure attachment is associated with the Pragma love type was also supported. The findings showed that individuals who are insecurely attached to their partners preferred the Pragma love type. Knowing the romantic partner well and seeing the relationship as a success and achievement are the specific characteristics of the Pragma love type (Galinha, Oishi, Pereira, et al., 2014). Furthermore, this pattern can be related to sensitivity to rejection. Individuals who know their partner well, especially those who understand their partner's expectations, can easily avoid situations they may be rejected in.

Consequently, they may be more likely to prefer the Pragma love type, and they can adjust their behaviors based on the partner's expectations and ensure their closeness to their partners. If they are not familiar with their partners, they may easily experience rejection. As a result, individuals who are insecurely attached to their partners can prefer the Pragma love style as a strategy to avoid their partner's rejection.

We hypothesized that there would be no difference between attachment styles in terms of Storge love type, which may be evaluated as friendship (Shaver and Hazan, 1988). Storge type of relationship is affected 
by attachment styles differently from the romantic love process, as our relationships with our friends are also thought to be influenced by our early experiences (Garrison, Kahn, Sauer, et al., 2012). In the context of adults' romantic attachment pattern, the preference of Storge love style is not different between attachment styles. In this way, our hypothesis is confirmed.

The literature suggests that securely attached people show higher general emotion expression while insecurely attached individuals, especially anxious ones, express more negative emotions. For instance, individuals who are insecurely attached to their partners can restrict or suppress their emotions and can avoid the expression of their emotions (Mikulincer and Shaver, 2007; Stroebe, Schut and Stroebe, 2005, 2006). Moreover, anxiously attached individuals exaggerate their feelings (Mikulincer and Shaver, 2007) and overstate the negative emotions experienced and have a regulatory influence on their partners' emotions with this way (Sbarra and Hazan, 2008); therefore, we hypothesized that individuals who are securely attached to their partners are expressing more general emotion; however, findings demonstrated that there were no significant differences between attachment styles in terms of expressing general emotions. In other words, contrary to our hypothesis, securely attached and insecurely attached individuals similarly disclose their emotions. As mentioned above, we coded attachment styles as secure and insecure, but to understand the association between attachment styles and emotional expression for further studies, subgroups of attachment styles (fearful, anxious, avoidant) may be examined following the literature.

On the other hand, our last hypothesis suggesting that securely attached people have higher life satisfaction was supported. Individuals who were securely attached to their partners showed more life satisfaction than individuals who were insecurely attached to their partners, as supported with previous studies (Reizer, 2015; Simpson, 1990; Stephan and Bachman, 1999). Individuals who have securely attached experience positive events more frequently and negative ones less often. Also, in contrast, individuals who were insecurely attached experience negative events more frequently (Simspon, 1990). This relationship may be since individuals with secure attachment focus more on positive traits and that individuals with insecure attachment seek more signs of rejection and avoidance from closeness 
(Bartholomew, 1990). Therefore, it is considered that the life satisfaction of individuals who are securely attached is expected to be higher. In this study, we evaluated whether the participants' positive and/or negative life experiences may affect their life satisfaction in accordance with their attachment styles; however, more studies need to be conducted even though our findings are supported by the general findings in the literature.

Although our findings, in general, are consistent with the literature, we can argue that the reason for the contradictory findings is since we considered the attachment styles to have two categories instead of four. We assessed the four attachment dimensions, which are presented by Experiences in Close Relationships, in two categories, which are insecure and secure attachment. For this reason, contrary to previous findings (Hazan and Shaver, 1987), the number of individuals with insecure attachment style in our sample was higher than individuals with secure attachment style. As we constantly repeat in the discussion section, there is a need for studies that use four categories of attachment styles.

Finally, we want to emphasize some limitations of the current study. First, the education level of the sample is quite high (bachelor and upper, $54.4 \%$ ). Researchers should not gloss over the fact that a sample that reflects the education level of the Turkish sample better behaves differently. Second, we measure the attachment style with a self-report scale; however, because currently this is not used much and new methods are used to measure it, it is necessary to examine the attachment style with different indicators and techniques. Last, Cronbach's Alpha of Ludus and Mania, which is the factor of the Love Attitudes Scale: Short Form, was lower than acceptable statistical cut-off at both translation-adaptation study and the current study. As mentioned above, preferring Ludus love type is related to seeing love as a game, and it is measured by four items. Two of them declare that the participant who answers them may have more than one romantic partners (e.g., I like to play a 'love game' with the person I am with and many others., Sometimes I have to prevent my romantic partner from learning about my other romantic partners).

Similarly, one of the four items of Mania love type states a similar context (e.g., If I suspect that the person I am with is with someone else, I cannot be at ease.). Having more than one romantic partner, and being able to state it is a challenging issue in Turkish society. This situation may have 
led to the participants evaluating those three items in different patterns from other items in Ludus and Mania factors; thus, Cronbach's Alphas of them may be obtained upper than acceptable statistical level. Consequentially, we recommend that other researchers who will use the findings of the current study should take into account all the limitations that we have expressed in this paragraph.

\section{Conclusions}

The differences between the characteristics and the life assessment of the individuals who are securely and insecurely attached to their partners can contribute to the literature in terms of examination of the expectations from the partners and the regulations of emotions in this direction when our results are evaluated in this context. This study has shown that romantic relationships are related to many factors. Providing counseling service in the context of attachment styles for couples in romantic relationships is considered to be particularly crucial for increasing life satisfaction in the light of these findings.

\section{References}

Adil, A. and Kamal, A. (2005). Relationship between love styles, attachment styles, and narcissism among university students. Indian Psychological Review, 64, $33-52$.

Ainsworth, M. D. S. (1979). Infant-mother attachment. The American Psychologist, 34(10), 932-937.

Doi:10.1037/0003-066X.34.10.932.

Akın, A. (2011). The validity and reliability of the Turkish version of the Berkeley Expressivity Scale. Procedia-Social and Behavioral Sciences, 30, 27-33.

Doi:10.1016/j.sbspro.2011.10.006.

Aron, A., and Westbay, L. (1996). Dimensions of the prototype of love. Journal of Personality and Social Psychology, 70(3), 535-551.

Doi:10.1037/0022-3514.70.3.535.

Bartholomew, K. (1990). Avoidance of intimacy: An attachment perspective. Journal of Social and Personal Relationships, 7(2), 147-178.

Doi:10.1177/0265407590072001.

Berscheid, E., and Walster, E. H. (1978). Interpersonal attraction (2 ${ }^{\text {nd }}$ ed.). Reading, MA: Addison Wesley.

Bowlby, J. (1969). Attachment and loss: Volume I, attachment. New York: Basic Books.

Bowlby, J. (1973). Attachment and loss: Volume II, separation anxiety and anger. New York: Basic Books.

Bowlby, J. (1980). Attachment and loss: Volume III, loss separation and depression. NewYork: Basic Books. 
Bugay, A. and Tezer, E. (2008, March). Attachment styles and loving attitudes among Turkish university students. Paper presented at the $2^{\text {nd }}$ Annual Global Conference: Persons, Intimacy and Love, Salzburg, Austria.

Büyükşahin, A. and Hovardaoğlu, S. (2004). Çiftlerin aşka ilişkin tutumlarının Lee'nin çok boyutlu aşk biçimleri kapsamında incelenmesi. Türk Psikoloji Dergisi, 19(54), 59-72.

Cassidy, J. (2008). The nature of the child's ties. In J. Cassidy, \& P. R. Shaver, (Eds.), Handbook of attachment: Theory, research, and clinical applications (pp. 3-22). New York, NY, US: Guilford Press.

Costa, A. L., Sophia, E. C., Sanches, C., Tavares, H. and Zilberman, M. L. (2015). Pathological jealousy: Romantic relationship characteristics, emotional and personality aspects, and social adjustment. Journal of Affective Disorders, $174,38-44$

Doi:10.1016/j.jad.2014.11.017.

Diener, E. D., Emmons, R. A., Larsen, R. J. and Griffin, S. (1985). The satisfaction with life scale. Journal of Personality Assessment, 49(1), 71-75.

Doi:10.1207/s15327752jpa4901_13.

Feeney, J. A. (2016). Adult romantic attachment: Developments in the study of couple relationships. In J. Cassidy, \& P. R. Shaver, (Eds.), Handbook of attachment: Theory, research, and clinical applications (pp. 435-463). New York, NY, US: Guilford Press.

Feeney, J. A. and Noller, P. (1990). Attachment style as a predictor of adult romantic relationships. Journal of Personality and Social Psychology, 58(2), 281-291.

Doi:10.1037/0022-3514.58.2.281.

Fraley, R. C., Heffernan, M. E., Vicary, A. M. and Brumbaugh, C. C. (2011). The experiences in close relationships-Relationship Structures Questionnaire: A method for assessing attachment orientations across relationships. Psychological Assessment, 23(3), 615-625.

Doi:10.1037/a0022898.

Fraley, R. C., Waller, N. G. and Brennan, K. A. (2000). An item response theory analysis of self-report measures of adult attachment. Journal of Personality and Social Psychology, 78(2), 350-365.

Doi:10.1037//0022-3514.78.2.350.

Fricker, J., \& Moore, S. (2002). Relationship satisfaction: The role of love styles and attachment styles. Current Research in Social Psychology, 7(11), 182-204.

Galinha, I. C., Oishi, S., Pereira, C. R., Wirtz, D. and Esteves, F. (2014). Adult attachment, love styles, relationship experiences and subjective well-being: Cross-cultural and gender comparison between Americans, Portuguese, and Mozambicans. Social Indicators Research, 119(2), 823-852.

Doi:10.1007/s11205-013-0512-7.

Garrison, A. M., Kahn, J. H., Sauer, E. M. and Florczak, M. A. (2012). Disentangling the effects of depression symptoms and adult attachment on emotional disclosure. Journal of Counseling Psychology, 59(2), 230-239. Doi:10.1037/a0026132. 
Gross, J. J. and John, O. P. (1995). Facets of emotional expressivity: Three selfreport factors and their correlates. Personality and Individual Differences, 19(4), 555-568.

Doi:10.1016/0191-8869(95)00055-B.

Grote, N. K. and Frieze, I. H. (1994). The measurement of friendship based love in intimate relationships. Personal Relationships, 1(3), 275-300.

Doi: 10.1111/j.1475-6811.1994.tb00066.x.

Hazan, C., and Shaver, P. (1987). Romantic love conceptualized as an attachment process. Journal of Personality and Social Psychology, 52(3), 511-524. Doi:10.1037//0022-3514.52.3.511.

Hendrick, C. and Hendrick, S. (1986). A theory and method of love. Journal of Personality and Social Psychology, 50(2), 392-402.

Doi:10.1037/0022-3514.50.2.392.

Hendrick, C., Hendrick, S. S. and Dicke, A. (1998). The love attitudes scale: Short form. Journal of Social and Personal Relationships, 15(2), 147-159. Doi:10.1177/0265407598152001

Honari, B. and Saremi, A. A. (2015). The study of relationship between attachment styles and obsessive love style.Procedia-Social and Behavioral Sciences, 165, 152-159.

Doi: $10.1016 /$ j.sbspro.2014.12.617.

Karandashev, V., Benton, M., Edwards, C. and Wolters, V. (2012). Development of attachment in romantic relationship of young adults with different love styles. Interpersona: An International Journal on Personal Relationships, 6(1), 1-22.

Karreman, A. and Vingerhoets, A. J. (2012). Attachment and well-being: The mediating role of emotion regulation and resilience. Personality and Individual Differences, 53(7), 821-826.

Doi:10.1016/j.paid.2012.06.014

Kennedy-Moore, E. and Watson, J. C. (2001). How and when does emotional expression help? Review of General Psychology, 5(3), 187-212.

Doi:10.1037//1089-2680.5.3.187.

Lee, J. A. (1973). Colours of love: An exploration of the ways of loving. Toronto: New Press.

Lee, J. A. (1988). Love-styles. In R. J. Sternberg and M. L. Barnes, (Eds.), The psychology of love (pp. 38-67). London: Yale University Press.

Levy, M. B. and Davis, K. E. (1988). Lovestyles and attachment styles compared: Their relations to each other and to various relationship characteristics. Journal of Social and Personal Relationships, 5(4), 439-471. Doi: $10.1177 / 0265407588054004$

Madey, S. F. and Rodgers, L. (2009). The effect of attachment and Sternberg's Triangular Theory of Love on relationship satisfaction. Individual Differences Research, 7(2), 76-84.

McWalter, C. (2012). Relationship satisfaction: the influence of attachment, love styles and religiosity. Unpublished master thesis, Dublin Business School.

Mikulincer, M. and Shaver, P. R. (2005). Attachment theory and emotions in close relationships: Exploring the attachment related dynamics of emotional reactions to relational events. Personal Relationships, 12(2), 149-168. 
Doi: $10.1111 / \mathrm{j} .1350-4126.2005 .00108 . \mathrm{x}$

Mikulincer, M. and Shaver, P. R. (2007). Attachment in adulthood: Structure, dynamics, and change. New York: Guilford Press.

Noh, E. J., Park, J. Y. and Kim, Y. H. (2006). The relationship among adult attachment types, love styles and dating of single people. Journal of the Korean Home Economics Association, 44(12), 31-42.

Prasoon, R. and Chaturvedi, K. R. (2016). Life satisfaction: A literature review. The Researcher-International Journal of Management Humanities and Social Sciences, 1(2), 25-32.

Raffagnino, R. and Puddu, L. (2018). Love styles in couple relationships: A literature review. Open Journal of Social Sciences, 6(12), 307-330.

Doi: $10.4236 /$ jss.2018.612027

Reis, H. T. and Aron, A. (2008). Love: What is it, why does it matter, and how does it operate? Perspectives on Psychological Science, 3(1), 80-86.

Doi:10.1111/j.1745-6916.2008.00065.x

Reizer, A. (2015). Influence of employees' attachment styles on their life satisfaction as mediated by job satisfaction and burnout. The Journal of Psychology, 149(4), 356-377.

Doi: $10.1080 / 00223980.2014 .881312$

Sbarra, D. A. and Hazan, C. (2008). Coregulation, dysregulation, self-regulation: An integrative analysis and empirical agenda for understanding adult attachment, separation, loss and recovery. Personality and Social Psychology Review, 12(2), 141-167.

Doi:10.1177/1088868308315702.

Schmitt, D. P. (2010). Romantic attachment from Argentina to Zimbabwe: Patterns of adaptive variation across contexts, cultures, and local ecologies. In K. M. $\mathrm{Ng}, \&$ P. Erdman, (Eds.), Cross-cultural attachment across the life-span (pp. 211-226). New York: Routledge.

Selçuk, E., Günaydın, G., Sümer, N. and Uysal, A. (2005). Yetişkin bağlanma boyutları için yeni bir ölçüm: Yakın Ilişkilerde Yaşantılar Envanteri-II'nin Türk örnekleminde psikometrik açıdan değerlendirilmesi. Türk Psikoloji Yazılart, 8(16), 1-11.

Shaver, P. R. and Hazan, C. (1988). A biased overview of the study of love. Journal of Social and Personal Relationships, 5(4), 473-501.

Doi:10.1177/0265407588054005

Simpson, J. A. (1990). Influence of attachment styles on romantic relationships. Journal of Personality and Social Psychology, 59(5), 971-980. Doi:10.1037//0022-3514.59.5.971.

Smith, R. and Klases, A. (2016). Predictors of love attitudes: The contribution of cultural orientation, gender attachment style, relationship length and age in participants from the UK and Hong Kong. Interpersona, 10(1), 90-108. Doi:10.5964/ijpr.v10i1.204

Stephan, C. W. and Bachman, G. F. (1999). What's sex got to do with it? Attachment, love schemas, and sexuality. Personal Relationships, 6(1), 111123.

Doi:10.1111/j.1475-6811.1999.tb00214.x 
Sternberg, R. J. (1986). A triangular theory of love. Psychological Review, 93(2), 119-135.

Doi:10.4135/9781412956253.n591.

Stroebe, M., Schut, H. and Stroebe, W. (2005). Attachment in coping with bereavement: A theoretical integration. Review of General Psychology, 9(1), 48-66.

Doi:10.1037/1089-2680.9.1.48

Stroebe, M., Schut, H. and Stroebe, W. (2006). Who benefits from disclosure? Exploration of attachment style differences in the effects of expressing emotions. Clinical Psychology Review, 26(1), 66-85.

Doi:10.1016/j.cpr.2005.06.009.

Sümer, N. (2006). Yetişkin bağlanma ölçeklerinin kategoriler ve boyutlar düzeyinde karşılaştırılması. Türk Psikoloji Dergisi, 21(57), 1-22.

Tacón, A. M., Caldera, Y. M. and Bell, N. J. (2001). Attachment style, emotional control, and breast cancer. Families, Systems \& Health, 19(3), 319-326. Doi:10.1037/h0089455.

Weiss, R. S. (1982). Attachment in adult life. In C. M. Parkes, \& J. StevensonHinde, (Eds.), The place of attachment in human behavior (pp. 171-184). New York: Basic Books.

Yetim, Ü. (1993). Life satisfaction: A study based on the organization of personal projects. Social Indicators Research, 29(3), 277-289.

Doi:10.1007/bf01079516.

Yetim, Ü. (2001). Toplumdan bireye mutluluk resimleri. İstanbul: Bağlam Yayıncilik.

\section{Footnotes}

1 According to Bartholomew's (1990) Four Categories Model, we extracted 4 clusters; dismissive avoidant, fearful, secure and preoccupied (see also, Sümer, 2006). We used Euclidean distance and Ward's method. 